\title{
Changes in the dynamics of migration aphids occurring on potato in Wielkopolska based on cathes of Johnsons suction trap in Winna Góra in 2002-2012
}

\author{
Zmiany w dynamice migracji mszyc żyjących na ziemniakach \\ w Wielkopolsce na podstawie odłowów aspiratorem Johnsona \\ w Winnej Górze w latach 2002-2012
}

Jan Złotkowski, Andrzej Bandyk

\section{Summary}

The study show the species composition of aphids colonizing potato crops in Poland. Data presented in this paper is based on the catches of aphids with Johnsons suction trap between the years 2002-2012 and describes, and compares long-term and seasonal dynamics flight intensity trophically related species of potatoes and of major importance in the epidemiology of viral diseases of their host plants. An attention was also paid to aphids colonizing potato crops accidentally and for short period, which by temporary feeding presents a of mechanical virus infection.

Key words: potato aphids, species composition, dynamics flight, potato

\section{Streszczenie}

Zbadano skład gatunkowy mszyc zasiedlających uprawy ziemniaka w Polsce. Na podstawie prowadzonych w latach 2002-2012 odłowów mszyc aspiratorem Johnsona przedstawiono i porównano także dynamikę wieloletnią i sezonową nasilenia lotów gatunków powiązanych troficznie z ziemniakami i mających duże znaczenie w epidemiologii chorób wirusowych swych roślin żywicielskich. Zwrócono uwagę na zagrożenie upraw ziemniaka ze strony mszyc zasiedlających ziemniaki przypadkowo i na krótko, stanowiąc również niebezpieczeństwo mechanicznego zakażenia wirusem.

Słowa kluczowe: mszyce ziemniaczane, skład gatunkowy, dynamika lotów, ziemniak

Instytut Ochrony Roślin - Państwowy Instytut Badawczy

Władysława Węgorka 20, 60-318 Poznań

j.zlotkowski@iorpib.poznan.pl 


\section{Wstęp / Introduction}

Spośród wielu gatunków mszyc, które mogą występować na ziemniakach, zaledwie pięć związanych jest pokarmowo $\mathrm{z}$ tą rośliną żywicielską. W pierwszej kolejności są to mszyca brzoskwiniowo-ziemniaczana Myzus persicae (Szulzer), gatunek holocykliczny, migrujący głównie $\mathrm{z}$ brzoskwini na różne rośliny zielne, zwłaszcza krzyżowe Cruciferae i psiankowate Solanaceae. Uznawany jest za jedynego w Polsce wektora o znaczeniu ekonomicznym wirusa liściozwoju ziemniaka (PLRV) oraz wirusa $\mathrm{Y}$ ziemniaka (PVY) i nieco słabszego wirusów $\mathrm{M}$ (PVM) i S (PVS). Kolejne holocyklicznie rozwijające się gatunki to: mszyca szakłakowo-ziemniaczana Aphis nasturtii (Kalt.) migrująca $\mathrm{z}$ szakłaka Rhamnus cathartica, rzadziej z kruszyny Rhamnus frangula na różne rośliny zielne, w tym na ziemniaki, na których jest efektywnym wektorem wirusów Y i M ziemniaka i słabszym wirusa $\mathrm{S}$ oraz mszyca kruszynowo ziemniaczana Aphis frangulae (Kalt.) migrująca $\mathrm{z}$ kruszyny na różne rośliny zielne, często na ziemniaki. Oceniana jest jako niezbyt efektywny wektor wirusów Y i $\mathrm{M}$ oraz prawdopodobnie wirusa $\mathrm{S}$ ziemniaka. Pozostałe dwa gatunki to mszyca smugowa Macrosiphum euphorbiae (Thom) i mszyca ziemniaczana średnia Aulacorthum solani (kalt.), obie rozwijające się holocyklicznie są gatunkami jednodomnymi zasiedlającymi między innymi ziemniak, na którym są wektorami wirusów Y i M i liściozwoju.

$\mathrm{Na}$ uprawy ziemniaka nalatują też inne gatunki mszyc nie związane żywicielsko $\mathrm{z}$ tą rośliną. Ich obecność, często bardzo krótka, nie jest obojętna gdyż, jak wykazały badania, około 10 gatunków $\mathrm{z}$ tej grupy mszyc może przenosić wirusy $\mathrm{Y}, \mathrm{M}$ i S w sposób nietrwały na kłujce, dokonując nakłuć próbnych ziemniaka, stając się w konsekwencji ich wektorami. Mszyce te występując na uprawach ziemniaka często znacznie przewyższają liczebnością kolonie mszyc żerujących na tej roślinie. Ponadto często wcześniej migrują na uprawy ziemniaka trafiając na młode rośliny, które nie nabyły jeszcze odporności związanej z wiekiem, przez co stają się jeszcze bardziej niebezpieczne (Kostiw i Robak 2008).

\section{Materiały i metody / Materials and methods}

Odłowy mszyc aspiratorem Johnsona były prowadzone w latach 2002-2012 na terenie Polowej Stacji Doświadczalnej Instytutu Ochrony Roślin - Państwowego Instytutu Badawczego w Winnej Górze, w odległości $50 \mathrm{~km}$ od Poznania. Aspirator o wysokości 12,2 m uruchamiano każdego roku w pierwszych dniach maja, a systematyczne odłowy trwały do końca listopada. Odłowione okazy mszyc wybierane codziennie o godzinie 13:00 były konserwowane $\mathrm{w} 70 \%$ propanolu i oznaczane do gatunku na bieżąco przy użyciu klucza (Blacman i Eastop 2000).

\section{Wyniki i dyskusja / Results and discussion}

Prowadzona w latach 2002-2012, w Winnej Górze, rejestracja migracji mszyc aspiratorem Johnsona wykazała we wszystkich latach, w odniesieniu do 5 gatunków atakujących uprawy ziemniaka, wyraźną dominację mszycy brzoskwiniowo-ziemniaczanej M. persicae (tab. 1, rys. 1).

Tabela 1. Sezonowa dynamika lotów pięciu gatunków mszyc żyjących na ziemniakach w Wielkopolsce rejestrowanych aspiratorem Johnsona w Winnej Górze w latach 2002-2012

Table 1. The dynamics of seasonal migration of aphids living on potatoes registered by Johnson suction trap between the years 2002-2012 in Winna Góra

\begin{tabular}{|c|c|c|c|c|c|c|c|c|c|c|c|c|}
\hline & Rok - Year & 2002 & 2003 & 2004 & 2005 & 2006 & 2007 & 2008 & 2009 & 2010 & 2011 & 2012 \\
\hline \multirow{4}{*}{ M. persicae } & wiosna - spring & 19 & 29 & 148 & 0 & 169 & 87 & 193 & 29 & 37 & 69 & 83 \\
\hline & lato - summer & 19 & 67 & 108 & 92 & 48 & 34 & 51 & 11 & 30 & 60 & 14 \\
\hline & jesień - autumn & 191 & 62 & 101 & 114 & 335 & 125 & 133 & 81 & 43 & 96 & 33 \\
\hline & suma - sum & 229 & 158 & 357 & 205 & 552 & 246 & 377 & 121 & 110 & 225 & 130 \\
\hline \multirow{4}{*}{ A. frangulae } & wiosna - spring & 1 & 1 & 60 & 0 & 10 & 17 & 38 & 1 & 26 & 13 & 33 \\
\hline & lato - summer & 16 & 4 & 51 & 54 & 16 & 10 & 10 & 19 & 8 & 11 & 3 \\
\hline & jesień - autumn & 0 & 0 & 0 & 0 & 0 & 12 & 6 & 9 & 1 & 3 & 0 \\
\hline & suma - sum & 17 & 5 & 111 & 54 & 26 & 39 & 54 & 29 & 35 & 27 & 36 \\
\hline \multirow{4}{*}{ A. nasturtii } & wiosna - spring & 0 & 6 & 58 & 5 & 47 & 10 & 34 & 0 & 22 & 30 & 74 \\
\hline & lato - summer & 3 & 15 & 62 & 23 & 4 & 6 & 27 & 0 & 31 & 40 & 7 \\
\hline & jesień - autumn & 4 & 1 & 0 & 0 & 11 & 7 & 0 & 5 & 0 & 15 & 0 \\
\hline & suma - sum & 7 & 22 & 120 & 28 & 62 & 23 & 61 & 5 & 53 & 85 & 81 \\
\hline \multirow{4}{*}{ A. solani } & wiosna - spring & 7 & 0 & 62 & 0 & 14 & 32 & 18 & 61 & 8 & 6 & 14 \\
\hline & lato - summer & 0 & 0 & 10 & 23 & 4 & 17 & 6 & 0 & 2 & 3 & 2 \\
\hline & jesień - autumn & 0 & 0 & 5 & 2 & 0 & 14 & 0 & 0 & 0 & 0 & 5 \\
\hline & suma - sum & 7 & 0 & 77 & 25 & 18 & 63 & 24 & 61 & 10 & 9 & 21 \\
\hline \multirow{4}{*}{ M. euphorbiae } & wiosna - spring & 10 & 7 & 33 & 0 & 0 & 3 & 8 & 1 & 0 & 0 & 6 \\
\hline & lato - summer & 0 & 14 & 0 & 16 & 0 & 10 & 2 & 0 & 0 & 4 & 16 \\
\hline & jesień - autumn & 0 & 0 & 0 & 0 & 3 & 0 & 0 & 0 & 0 & 0 & 0 \\
\hline & suma - sum & 10 & 21 & 33 & 16 & 3 & 13 & 10 & 1 & 0 & 4 & 22 \\
\hline
\end{tabular}


Mszyca ta $\mathrm{w}$ proporcji do wszystkich rejestrowanych aspiratorem gatunków (około 100 gatunków w każdym roku), plasuje się pod względem liczebności zwykle w grupie subdominantów stanowiącej 2,1-5,0\% ogółu odłowionych mszyc (Złotkowski i Bandyk 2012). W omawianym okresie badań mszyca ta wykazywała rok do roku dużą zmienność liczebności i po okresie wysokich wzrostów, po roku 2006, obserwowano wyraźny spadek jej frekwencji w odłowach (tab. 1, rys. 1). Zarejestrowane aspiratorem dwa gatunki: $A$. frangulae i $A$. nasturtii liczone przy analizie migracji jako suma osobników, ze względu na bardzo podobną biologię rozwoju i zbliżony termin ich pojawu na uprawach, wykazywały w omawianym okresie badań, w porównaniu z $M$. persicae znacznie niższą frekwencję w odłowach, osiągając jedynie w 2004 roku zwiększoną liczebność, która w kolejnych latach ponownie zmalała (tab. 1, rys. 1). Pozostałe dwa gatunki mszyc uznawane za szkodniki ziemniaków: M. euphorbiae i A. solani, wykazały przez cały okres badań minimalną frekwencję w odłowach, znacznie poniżej $1 \%$ ogółu zarejestrowanych gatunków - klasa subrecedentów. Wcześniejsze badania na uprawach ziemniaka wykonane

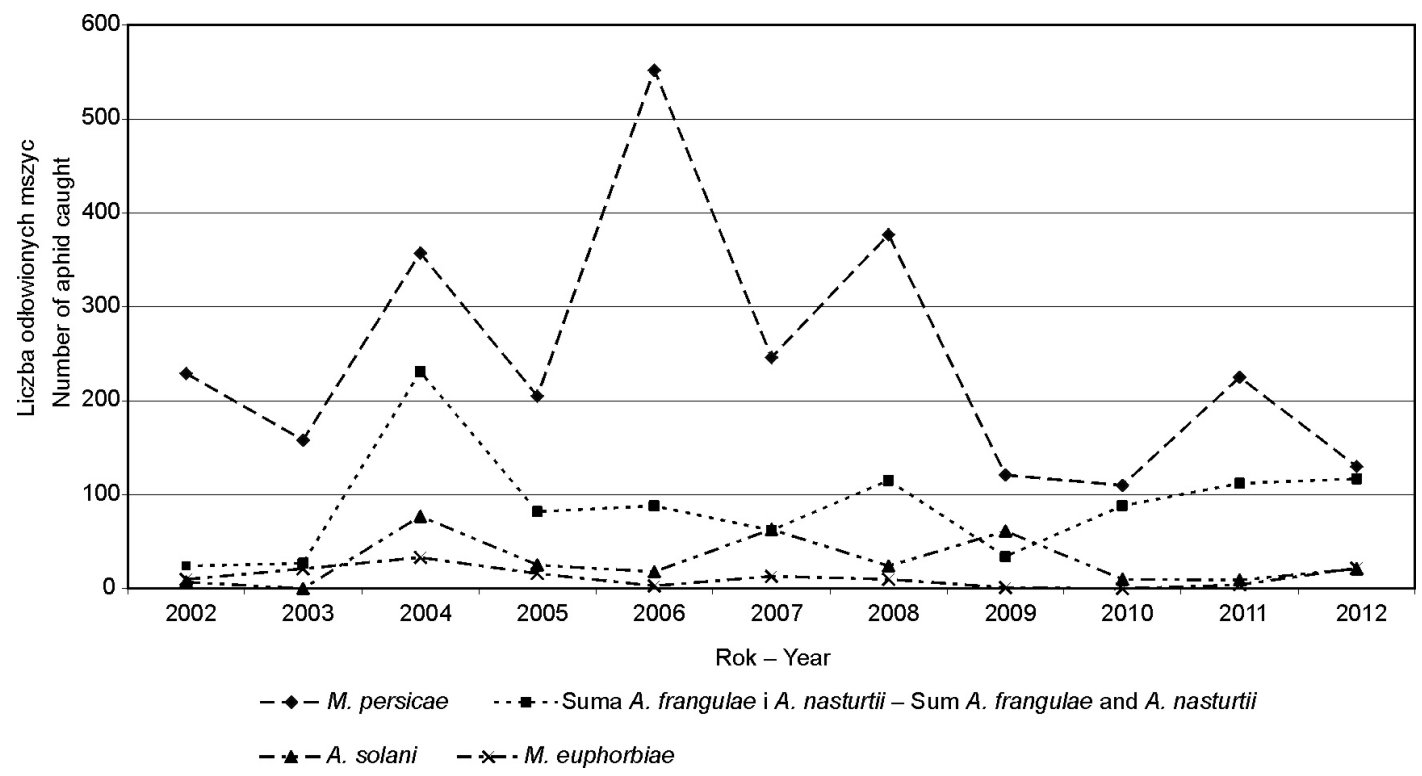

Rys. 1. Dynamika mszyc występujących na ziemniakach w odłowach aspiratorem Johnsona w latach 2002-2012 w Wielkopolsce

Fig. 1. The dynamics of migration of aphids living on potatoes in catches performed by Johnson aspirator between the years $2002-2012$ in Wielkopolska

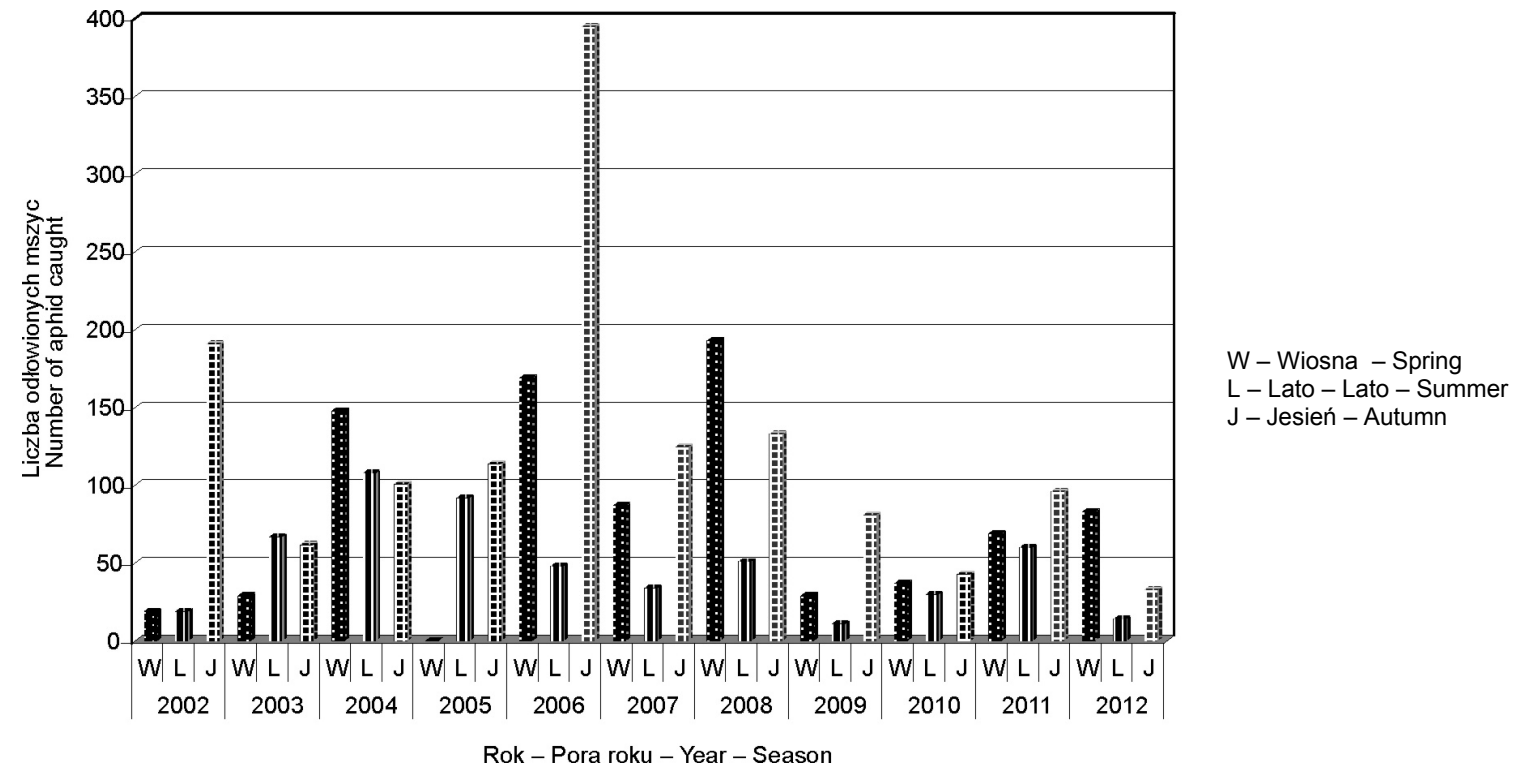

Rys. 2. Dynamika sezonowa migracji mszycy brzoskwiniowo-ziemniaczanej M. persicae na podstawie odłowów aspiratorem Johnsona w latach 2002-2012

Fig. 2. The dynamics of seasonal migration in the aphid M. persicae in catches performed by Johnson aspirator between the years 2002-2012 


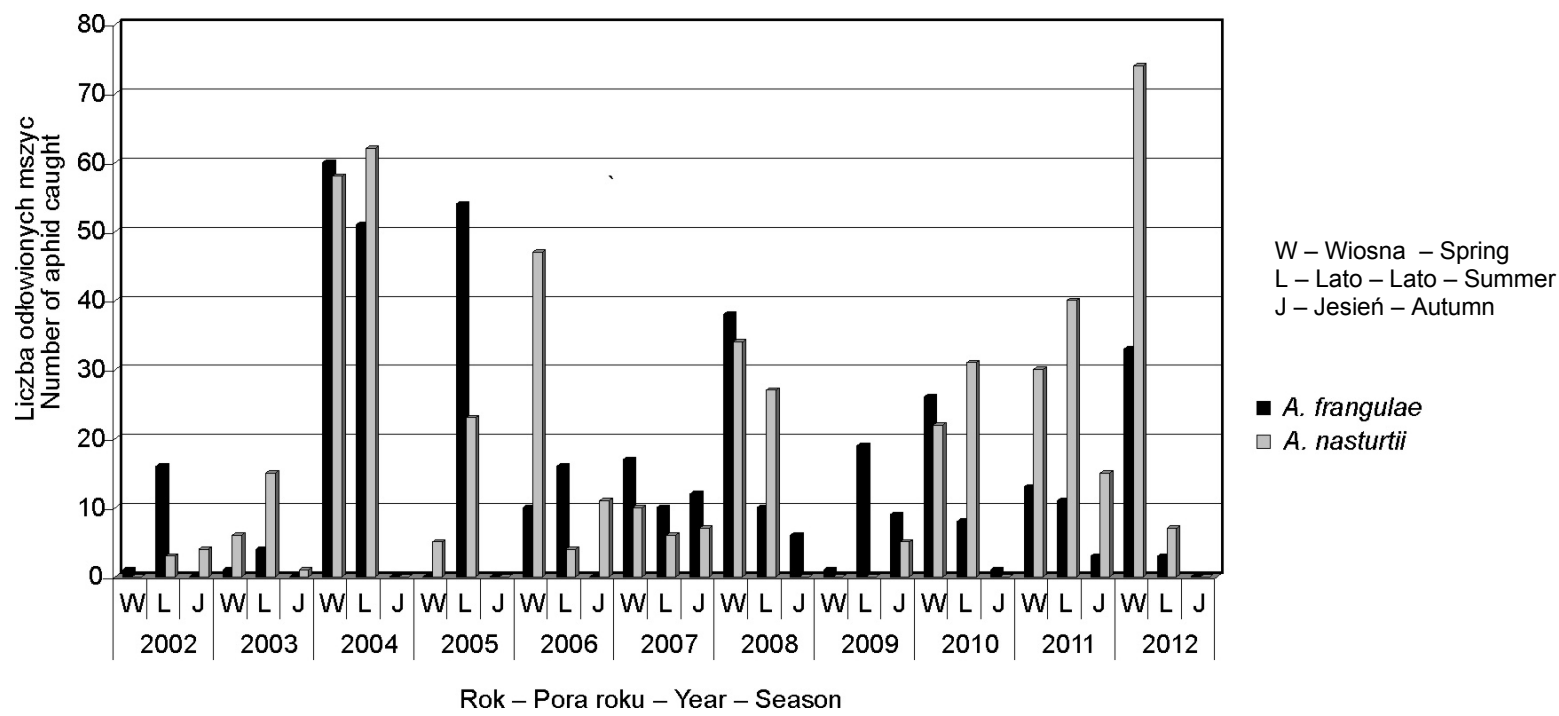

Rys. 3. Dynamika sezonowa migracji dwóch gatunków mszyc $A$. frangulae i A. nasturtii na podstawie odłowów aspiratorem Johnsona w latach 2002-2012

Fig. 3. The dynamics of seasonal migration of the species $A$. frangulae and $A$. nasturtii in catches performed by Johnson aspirator between the years2002-2012

przez innych badaczy w kilku regionach Polski również wykazały, że oba gatunki występowały sporadycznie (Kostiw 1987). Prowadząc obserwacje w rejonie Wrocławia stwierdzono, że mszyca M. euphorbiae wystąpiła dość licznie, osiągając 14\% ogółu zebranych mszyc (Hurej i wsp. 2003). Podobna sytuacja dotyczy mszyc: A. frangulae i $A$. nasturti, które na podstawie liczebności w odłowach aspiratorem Johnsona zaliczono do klasy subrecedentów - poniżej 1\% ogółu zarejestrowanych mszyc (Złotkowski i Bandyk 2012), natomiast z badań Kostiwa i Robaka (2012) wynika, że na uprawach ziemniaka liczebność tych gatunków była we wszystkich miejscowościach, w których prowadzono obserwacje wielokrotnie, wyższa niż $M$. persicae.

Analizując przebieg migracji mszycy brzoskwiniowoziemniaczanej $M$. persicae w ujęciu sezonowym: wiosna, lato, jesień, stwierdzono niejednakowe nasilenie lotów w całym sezonie wegetacyjnym. W przypadku tego gatunku zwykle najliczniejsze przeloty miały miejsce w okresie jesiennym (tab. 1, rys. 2) i związane były $z$ jego reemigracją na gospodarzy zimowych. Należy podkreślić, że początek migracji wiosennej $M$. persicae na podstawie odłowów aspiratorem występował każdego roku wcześniew drugiej połowie maja lub na przełomie maja i czerwca, a liczniejsze naloty wiosna, zwłaszcza w latach: 2004, 2008 i 2012 (rys. 2), przypadały w czasie, gdy uprawy ziemniaka były młode i mało odporne na uszkodzenia. Najliczniejsze migracje mszyc $A$. frangulae i $A$. nasturtii zaobserwowano w okresie wiosny i lata, natomiast w latach 2004, 2005, 2012 (tab. 1, rys. 3) w okresie jesiennym zdarzało się, że gatunki te w ogóle nie były odławiane.
Pozostałe gatunki $A$. solani i $M$. euphorbicae występowały nielicznie i nie każdego roku, co wskazuje, że nie mają one większego znaczenia ekonomicznego w uprawach ziemniaka.

\section{Wnioski / Conclusions}

1. Wśród kilkunastu gatunków mszyc występujących co roku na uprawach ziemniaka tylko pięć jest powiązanych troficznie $\mathrm{z}$ tą rośliną żywicielską. Są to: M. persicae, A. frangulae, A. nasturtii, A. solani i M. euphorbiae.

2. Duże znaczenie w epidemiologii chorób wirusowych mają mszyce: $M$. persicae, $A$. frangulae, $A$. nasturtii i jednocześnie są one każdego roku, spośród wszystkich pięciu gatunków żyjących na ziemniakach, częściej odławiane aspiratorem Johnsona.

3. Analizując sezonowy przebieg migracji mszycy M. persicae stwierdzono, że najliczniej gatunek ten odławia się w okresie jesiennym. W niektórych latach, wczesna wiosenna migracja $\mathrm{w}$ drugiej połowie maja i liczne w tym czasie przeloty powoduja, że mszyca ta staje się szczególnie niebezpieczna dla młodych i podatnych na wszelkie uszkodzenia roślin ziemniaka.

4. Największe nasilenie lotów $A$. frangulae oraz $A$. nasturtii przypada zwykle na okres wiosny i lata.

5. Gatunki A. solani i M. euphorbiae były odławiane aspiratorem pojedynczo i nie każdego roku. 


\section{Literatura / References}

Blacman R.L., Eastop V.F. 2000. Aphids on the Words Crops, an Identification and Information Guide, Second Edition. The Natural History Museum, London, 466 pp.

Hurej M., Goos M., Twardowski J. 2003. Porównanie składu gatunkowego mszyc ziemniaczanych na Dolnym Śląsku w ostatnim dwudziestoleciu. s. 49-51. Konferencja Nasiennictwo i Ochrona Ziemniaka. Bonin, IHAR, ZNiOZ Kołobrzeg, 24-25 kwietnia 2003. 355 ss.

Kostiw M. 1987. Przenoszenie ważniejszych wirusów ziemniaka przez mszyce. Instytut Ziemniaka, Bonin, 105 ss.

Kostiw M., Robak B. 2008. Skład gatunkowy, termin migracji i dynamika liczebności mszyc „nieziemniaczanych” w uprawie ziemniaka $\mathrm{w}$ różnych rejonach kraju. [Species composition, migration period and dynamics of number of no potato colonizing aphids in different regions of Poland]. Prog. Plant Prot./Post. Ochr. Roślin 48 (3): 881-888.

Kostiw M., Robak B. 2012. Dynamika liczebności mszyc, wektorów wirusów, w latach 2010-2012 i zagrożenie plantacji ziemniaka przez wirusy Y i liściozwoju w 2012 r. Ziemniak Polski 4: 18-23.

Złotkowski J., Bandyk A. 2012. Charakterystyka zmian w strukturze składu gatunkowego mszyc migrujących w odłowach aspiratorem Johnsona w latach 1999-2010. [Characteristics of the changes in the structure of aphid species composition based catches of Johsons suction trap in 1999-2010]. Prog. Plant Prot./Post. Ochr. Roślin 52 (2): 252-258. 